\title{
KEWENANGAN MENGADILI ATAS PENERAPAN CHOICE OF LAW PADA ASURANSI PENGANGKUTAN LAUT
}

\author{
Ni Made Debi Ade Viskesia, I Nyoman Putu Budiartha, I Putu Gede Seputra \\ Fakultas Hukum Universitas Warmadewa, Denpasar-Bali, Indonesia \\ debiviskesia@gmail.com, budiarthaputu59@gmail.com,gamyongputu@gmail.com
}

\begin{abstract}
Abstrak
Pengangkutan saat ini berkembang sangat pesat didalam aspek kehidupan, sudah banyak angkutan yang memberi harga lebih murah dari angkutan lainnya. Untuk menghindari risiko-risiko dalam pengangkutan laut menggunakan asuransi pengangkutan laut, namun asuransi pengangkutan laut masih menggunakan hukum inggris dan ketentuan-ketentuannya. Sehingga dalam perjanjian asuransi pengangkutan laut berlakunya pilihan hukum. Penelitian mengkaji kedudukan pilihan hukum (choice of law) dalam penyelesaian sengketa pengangkutan laut dan menjelaskan prosedur dalam penyelesaian sengketa pilihan hukum atas kewenangan mengadili pengangkutan laut. Penelitian ini menggunakan metode penelitian normatif dengan pendekatan Perundang-undangan dikarenakan masih terdapat konflik norma, dengan bersumber pada data primer dan sekunder. Dalam Kitab Undang-undang hukum perdata pasal 1320 dan 1338 telah ditentukan syarat sahnya suatu perjanjian dan perjanjian yang dibuat secara sah akan menjadi Undang-undang bagi mereka yang membuatnya. Sehingga terlepas dari hal itu pilihan hukum dalam kewenangan mengadili terdapat juga dalam hukum perdata internasional, dengan hal demikian dalam penyelesaian sengketa asuransi pengangkutan laut yang masih menggunakan hukum inggris dapat diselesaikan dengan melihat fakta-fakta yang ada dalam perjanjian asuransi pengangkutan laut dengan hukum-hukum yang berlaku.
\end{abstract}

Kata Kunci : Asuransi Pengangkutan Laut, Kewenangan Mengadili, Pilihan Hukum

\begin{abstract}
Transportation is currently developing very rapidly in the aspect of life, there are many transportations that provide cheaper prices than other transportation. To avoid the risks in sea transportation using sea freight insurance, but sea freight insurance still uses English law and its provisions. So that in the sea transportation insurance agreement the choice of law applies. The study examines the position of the choice of law in the settlement of maritime transportation disputes and explains the procedure for resolving disputes over the choice of law on the authority to adjudicate sea transportation. This study uses a normative research method with a statutory approach because there is still a conflict of norms, sourced from primary and secondary data. In the Civil Code Articles 1320 and 1338 it has been determined that the conditions for the validity of an agreement and agreements made legally will become law for those who make them. So apart from that, the choice of law in the jurisdiction to adjudicate is also contained in international civil law, thus in the settlement of maritime transportation insurance disputes that still use English law, it can be resolved by looking at the facts contained in the sea freight insurance agreement with the applicable laws. apply.
\end{abstract}

Keywords: Sea Freight Insurance, Judgment Authority, Choice of Law

\section{PENDAHULUAN}

Pengangkutan memiliki peran penting dalam memajukan dan memperlancar perdagangan dalam maupun luar negeri, karena dapat memperlancar arus barang dari satu tempat ke tempat lainnya. Pada perkembangan saat ini jasa pengangkutan di Indonesia mulai menunjukan kemajuan, dilihat dari banyaknya perusahaan industri yang percaya untuk menggunakan jasa pengangkutan. Pengangkutan melalui laut paling banyak digunakan karena dapat memberikan keuntungan-keuntungan seperti biaya angkut yang jauh lebih murah dibandingkan biaya pengangkutan lainnya dan pengangkutan laut yang dapat membawa penumpang sekaligus memuat barang yang beratnya ratusan ton (Soekardono, 1969). Selain adanya keuntungan dari pengangkutan, adapun risiko-risiko yang terjadi dalam pengangkutan laut seperti, kesalahan yang terjadi karena bencana alam, kesalahan yang terjadi karena pihak jasa pengangkut itu sendiri dan kesalahan yang terjadi karena kelalaian dari pihak penumpang atau barang yang diangkut. Untuk mengalihkan risiko-risiko dalam pengangkutan laut dialihkan dalam asuransi pengangkutan laut yang telah di atur dalam pasal 468 dan $472 \mathrm{KUHD}$, dan diatur secara jelas dalam 
UU No. 40 Tahun 2014 tentang Pengasuransian. Pengangkutan laut terjadi bila mana pihak penerima jasa pengangkutan melakukan perjanjian dengan pihak jasa pengangkutan. Dalam perjanjian pengangkutan laut, masih ada beberapa jasa pengangkutan laut masih menggunakan hukum inggris dan ketentuan-ketentuannya.

Maka dalam perjanjian pengangkutan laut adanya pilihan hukum yang digunakan, dimana pilihan hukum merupakan kebebasan para pihak untuk memilih sendiri hukum yang digunakan dalam perjanjian. Sehingga bilamana terjadi sengketa pilihan hukum, maka untuk memilih kewenangan mengadili sengketa pilihan hukum dapat dengan jelas digunakan untuk memeriksa dan memutus suatu perkara dalam perjanjian pilihan hukum. Perjanjian pengangkutan laut terjadi antara perseorangan dengan perusahaan yang berbadan hukum atau perusahan berbadan hukum dengan perusahaan berbadan hukum (Marthen, 2015) \& (Siswanto \& Sari, 2010). Perjanjian pengangkutan laut dilakukan oleh jasa pengangkutan laut dengan jasa asuransi pengangkutan laut (Moertiono, 2019). Berdasarkan latar belakang di atas, maka penelitian ini dilakukan untuk mengkaji kedudukan pilihan hukum (choice of law) dalam penyelesaian sengketa pengangkutan laut dan menjelaskan prosedur dalam penyelesaian sengketa pilihan hukum atas kewenangan mengadili pengangkutan laut

\section{METODE PENELITIAN}

Tipe penelitian yang digunakan dalam penulisan ini adalah tipe penelitian Hukum Normatif oleh karenanya pengkajian dilakukan melalui studi kepustakaan, dengan pendekatan masalah adalah pendekatan Perundang-undangan yang berlaku dan berkaitan dengan permasalahan secara konseptual yaitu menganalisis permasalahan yang akan dibahas melalui konsep-konsep hukum yang diambil dari buku-buku dan literatur-literatur yang ada relevansinya dengan permasalahan dalam kewenangan mengadili atas penerapan choice of law pada asuransi pengangkutan laut (Bambang, 2002). Adapun sumber bahan hukum dalam penelitian ini menggunakan yaitu sumber bahan hukum primer dan sekunder. Sumber bahan hukum primer adalah sumber bahan hukum yang bersifat mengikat seperti peraturan Perundang-undangan yang digunakan berkaitan dengan penelitian mengenai pilihan dalam kewenangan mengadili sengketa asuransi pengangkutan laut. Sedangkan bahan hukum sekunder yaitu bahan hukum yang di dapat dari literatur-literatur, karya ilmiah ataupun pendapat para sarjana mengenai penelitian ini. Setelah data-data penelitian terkumpul maka selanjutnya dianalisis secara deskriptif analisis dan disajikan secara sistematis (Pakaya, 2017).

\section{HASIL DAN PEMBAHASAN}

\section{Kedudukan Pilihan Hukum (Choice Of Law) dalam Penyelesaian Sengketa Asuransi Pengangkutan Laut}

Pilihan hukum merupakan kebebasan para pihak untuk memilih sendiri hukum mana yang akan dipilih dalam melakukan suatu perjanjian. Dalam asuransi pengangkutan laut sering kali ditemui istilah pilihan hukum, namun masih banyak perusahaan asuransi pengangkutan laut masih menggunakan hukum inggris. Dalam pilihan hukum, orang dapat menentukan sendiri hukum mana yang berlaku, namun dalam konteks kekinian persoalan pilihan hukum masih dipersoalkan antara para sarjana yaitu menyangkut batas wewenang untuk memilih hukum tersebut (Gautama, 1977).

Pilihan hukum didasari pada asas kebebasan berkontrak yaitu para pihak memiliki kebebasan untuk menyepakati kontrak diantara mereka, dalam batas-batas tertentu. Pilihan hukum dalam kontrak Internasional akan timbul ketika kontrak terjadi antara pihak-pihak yang berasal dari yurisdiksi hukum yang berbeda-beda. Sebagai salah satu contoh pada sengketa PT. Asuransi Harta Aman Pratama dengan warga negara Amerika yang disepakati oleh Badan Hukum Inggris. Umumnya pilihan hukum akan dipilih dari salah satu pihak dalam kontrak. Penentuan hukum ini dalam praktiknya dipengaruhi oleh banyak faktor antara lain, pengetahuan para pihak terhadap hukum yang dipilih untuk berlaku untuk kontrak mereka. Misalnya, hukum inggris adalah hukum yang selalu dipilih dalam kontrak-kontrak asuransi dan pengangkutan laut.

Pilihan hukum muncul dalam praktik peradilan di Indonesia ketika dalam kontrak mendatangkan sengketa. Pengadilan Indonesia tidak dapat menyelesaikan sengketa yang mengandung hukum asing, walaupun sudah diatur asas kebebasan berkontrak pada KUH Perdata. Apabila Hukum Perdata Internasional (HPI) sudah menentukan bahwa hukum asing harus diberlakukan, namun manakala pemakaian hukum asing tersebut menjadi suatu pelanggaran peraturan-peraturan nasional setempat, maka hukum asing dapat dikesampingkan atas dasar demi kepentingan umum. Dalam hal 
ini disebut "ketertiban umum" yang dimana fungsinya sebagai penghalang terhadap berlakunya hukum asing tersebut. Dalam kaidah HPI Negara yang bersangkutan seharusnya dipergunakan (lex causae), maka hakim dapat mengesampingkan hukum asing tersebutm (Gautama, 2007). Dalam perjanjian asuransi, para pihak menyepakati bahwa "This insurance is subject to English law and practice". Sementara itu pilihan peradilan dalam perjanjian asuransi PT. Asuransi Harta Aman Pratama dalam persidangan menolak sengketa asuransi ini diselesaikan di Pengadilan negeri Denpasar, karna menurut PT. Asuransi Harta Aman Pratama dengan PT. Tirta Internasional Cargo telah menyetujui hukum dan ketentuannya berdasarkan hukum inggris. Maka dari itu menurut PT. Asuransi Harta Aman Pratama, sengketa ini seharusnya diperiksa dan diadili oleh Pengadilan Inggris dikarenakan Hukum Inggris berlaku terhadap kontrak asuransi ini. Dalam hal ini pilihan hukum yang sudah disepakati dalam perjanjian masih membuat satu pihak bingung, karena dilihat dari faktafaktanya dalam perjanjian yang dibuat di Bali, Indonesia, pihak yang melakukan perjanjian yaitu Perseroan Terbatas (PT) yang berdiri dengan hukum di Indonesia, dan barang yang dikirim dari Bali, Indonesia menuju Amerika. Jadi, dilihat dari hal tersebut pilihan yurisdiksi dalam menyelesaikan sengketa tersebut seharusnya dapat diselesaikan di Pengadilan Negeri Denpasar.

Dalam perjanjian ini dibuat perjanjian asuransi pengangkutan laut. Asuransi Pengangkutan Laut (Marine Cargo Insurance) yaitu suatu jaminan pertanggungan ganti rugi yang diberikan oleh jasa asuransi kepada penerima jasa asuransi tersebut terhadap barang yang diangkut dari tempat asal menuju tempat tujuan dengan selamat. Dalam pasal $255 \mathrm{KUH}$ Dagang sudah dijelaskan bahwa perjanjian asuransi akan berlaku bilamana dinyatakan dalam perjanjian tertulis dan diberikan Bea Materai secukupnya.

Polis yang digunakan dalam asuransi pengangkutan laut yaitu polis dengan jangka waktu 3 bulan, 6 bulan, 12 bulan atau lebih. Yang pada umumnya digunakan ialah polis jangka waktu 12 bulan dan polis perjalanan atau bolak balik. Adapun premi asuransi dari pengangkutan laut yaitu premi yang harus dibayar oleh pihak tertanggung dengan besar kecilnya nominal dari premi tersebut sesuai kesepakatan para pihak dalam perjanjian.Bahaya yang diasuransikan yaitu bahaya maritime dan non maritime. Bahaya maritime yaitu bahaya yang disebabkan dari alam contohnya gelombang besar yang mengakibatkan kapal tenggelam. Sedangkan, bahaya non maritime yang disebabkan oleh kelalaian manusia sendiri, contohnya kelalaian dalam mengemudi kapal sehingga kapal tertabrak benda yang membuat kebakaran di tengah laut.

Seperti dalam kasus PT. Asuransi Harta Aman Pratama dengan orang berkewarganegaraan Amerika, penyelesaian sengketa dalam perkara ini adalah tunduk dan berdasarkan pada hukum di negara Inggris seperti dimaksud dalam Pasal 19 Polis Asuransi. Pilihan hukum seperti demikian ini adalah tidak tepat dan berdasar karenanya PT. Internasional Cargo yang diberi kekuasaan penuh oleh orang berkewarganegaraan Amerika menolak dengan tegas tentang perihal ini, mengingat PT. Asuransi Harta Aman Pratama merupakan badan hukum yang didirikan berdasarkan hukum di Indonesia dan disamping itu barang-barang yang dikirim dalam perkara ini berasal dari Indonesia bukan dari Inggris sehingga sama sekali tidak ada korelasinya dengan sistem hukum pada Negara Inggris. PT. Asuransi Harta Aman Pratama tidak bersedia membayarkan tuntutan klaim asuransi sesuai dengan nilai yang dijaminkan, karena sesungguhnya lingkup pertanggungan asuransi adalah warehouse to warehouse sebagaimana tertera dalam perjanjian asuransi, sehingga tidak ada alasan bagi Tergugat untuk menolak permintaan/tuntutan klaim asuransi karena dahulu hal tersebut telah diperjanjikan dan terhadap perbuatan Tergugat seperti demikian ini tergolong sebagai perbuatan wanprestasi.

\section{Prosedur dalam Penyelesaian Sengketa Pilihan Hukum atas Kewenangan Mengadili Pengangkutan Laut}

Kewenangan mengadili yaitu kewenangan dalam menentukan pengadilan yang berwenang dalam memeriksa dan memutuskan suatu perkara tanpa adanya penolakan dari pihak pengadilan atas alasan bahwa pengadilan tidak berwenang dalam menyelesaikan sengketa. Kewenangan mengadili dibagi menjadi dua yaitu kewenangan absolut dan kewenangan relatif. Penyelesaian Sengketa Pengangkutan Laut bisa diselesaikan dengan dua jalur yaitu jalur diluar pengadilan atau yang sering disebut jalur damai dan jalur melalui pengadilan umum atau negeri (Nasution, 1999).

Dalam perkembangannya bentuk penyelesaian sengketa diluar pengadilan digunakan dapal penyelesaian sengketa di dalam peradilan, yaitu seperti contoh mediasi yang dimana Peraturan 
Mahkamah Agung No. 2 Tahun 2003 Tentang Prosedur Mediasi di Pengadilan, maka setiap perkara perdata tertentu yang akan diadili oleh hakim pengadilan dalam lingkungan peradilan umum dan peradilan agama diwajibkan terlebih dahulu untuk menempuh proses mediasi yang dilakukan oleh mediator di pengadilan umum atau pengadilan agama. Sehingga seperti dalam contoh kasus sengketa kedudukan pilihan hukum (choice of law) pada Asuransi Pengangkutan Laut PT. Asuransi Harta Aman Pratama yang menggunakan alternatif penyelesaian kasus melalui pengadilan (litigasi).

Dalam sengketa ini penyelesaian dilakukan di Pengadilan Negeri Denpasar dengan Putusan Mahkamah Agung Nomor 147/K/Pdt/2014. Para Pemohon Kasasi yang dalam hal ini disebutkan PT. Tirta Internasional Cargo dan orang berkewarganegaraan Amerika, mengajukan Kontra Memori Kasasi sebagai bentuk keberatan atas Memori Kasasi yang diajukan oleh Termohon Kasasi yang dalam hal ini disebutkan PT. Asuransi Harta Aman Pratama dahulu Terbanding/ Tergugat terhadap Putusan Pengadilan Tinggi Denpasar No. 130/Pdt/2009/PT.Dps tertanggal 04 Maret 2010 Jo Putusan Pengadilan Negeri Denpasar No.195/Pdt.G/2009/PN.Dps, tertanggal 10 Agustus 2009. Dalam tingkat kasasi ini PT. Tirta Internasional Cargo yang sudah diberi kuasa penuh oleh orang berkewarganegaraan Amerika melanjutkan penyelesaian sengketa pada tingkat kasasi melawan PT. Asuransi Harta Aman Pratama. Dalam kasasi ini PT. Tirta Internasional Cargo atau yang disebut Termohon kasasi mengajukan Kontra Memori Kasasi dengan alasan-alasan yang sesuai dengan ketentuan Pasal 30 ayat 1 Undang-undang Mahkamah Agung, alasan kasasi yang sah dan bernilai untuk dipertimbangkan Majelis Hakim pada Pengadilan Tingkat Kasasi adalah :

1. Tidak berwenang Mengadili atau melampaui batas wewenang

2. Salah menerapkan atau melanggar hukum yang berlaku

3. Lalai memenuhi syarat yang diwajibkan oleh peraturan perundang-undangan yang mengancam kelalaian itu dengan batalnya putusan yang bersangkutan.

Jadi, alasan kasasi yang dibenarkan undang undang, sangat terbatas atau limitatif hanya 3 aspek saja dan tidak bisa diperluas selain daripada itu. Pada tingkat kasasi ini penyelesaian sengketa memperhatikan mengenai kewenangan mengadili secara absolut, yang dimana diperjelas lagi bahwa penyelesaian sengketa ini bisa diputuskan di Pengadilan Negeri Denpasar dengan peraturan Perundang-undangan yang sudah ada di Indonesia yang mengatur Asuransi Pengangkutan dan Perundang-undangan lainnya yang menyangkut sengketa Kewenangan Mengadili Atas Penerapan Choice Of Law Pada Asuransi Pengangkutan Laut. Awal mulanya sengketa ini tidak bisa diselesaikan di Pengadilan Negeri Denpasar dikarenakan dalam perjanjian asuransi tersebut menggunakan Hukum Inggris "This insurance is subject to English law and practice".

Namun dilihat dari kedudukan Pemohon kasasi (PT. Asuransi Harta Aman Pratama) dan Termohon kasasi II (PT. Tirta Internasional Caro) bukan merupakan hubungan hukum yang bersifat transnasional (melewati batas atau yurisdiksi negara), bahkan perikatan tersebut dilakukan oleh 2 badan hukum (perseroan) yang sama-sama tunduk dan didirikan berdasarkan Hukum Negara Republik Indonesia, dalam hal ini Undang Undang No. 1 Tahun 1995 sebagaimana telah diubah menjadi Undang Undang No. 40 Tahun 2007 tentang Perseroan Terbatas. Dan bila mana perjanjian dibuat oleh kedua belah pihak, ketika perjanjian tersebut dibuat oleh para pihak yang sama-sama berada negara yang sama, maka secara hukum yang berlaku yaitu dari tempat perjanjian tersebut dibuat (Fuady, 2007).

Dilihat dari Declaration Theory, yang dianggap telah menutupi kelemahan Teori Lex Loci Contractus berkenaan dengan pernyataan pihak yang melakukan perikatan, maka hukum yang berlaku adalah hukum dimana pihak yang menerima penawaran (offer) menyatakan penerimaan untuk itu. Mengingat bahwa Pemohon Kasasi dahulu Terbanding atau Tergugat melalui karyawannya di Kantor Cabang Denpasar, dalam perkara aquo merupakan pihak yang menawarkan produk/ jasa asuransi kepada Termohon Kasasi II dahulu Pembanding II/ Penggugat II dengan iming-iming bahwa proses pengurusan dokumen mudah dan pencairan klaim dapat cepat dilakukan sedemikian hingga akhirnya Termohon Kasasi II dahulu Pembanding II/Penggugat II mau menerima produk asuransi yang ditawarkan tersebut (kecuali dalam hal pilihan hukum) dan Termohon Kasasi II dahulu Pembanding II/ Penggugat II menyatakan penerimaan asuransi tersebut di Denpasar, bukan di Jakarta apalagi di Inggris, sehingga sudah merupakan hal yang patut bilamana perkara aquo diperiksa dan diadili di Pengadilan Negeri Denpasar. 


\section{SIMPULAN DAN SARAN}

\section{Simpulan}

Berdasarkan analisis data, dapat diisimpulkan bahwa Kedudukan pilihan hukum dalam penyelesaian sengketa antara orang berkewarganegaraan amerika dan PT. Tirta Internasional Cargo melawan PT. Asuransi Harta Aman Pratama melihat pada kaidah Hukum Perdata Internasional yang dimana hukum asing dapat berlaku, namun apabila hukum asing merupakan pelanggaran sendi-sendi pokok hukum nasional maka hukum asing tersebut dapat dikesampingkan demi ketertiban umum dengan hukum yang seharusnya berlaku (lex fori). Dan dalam kaidah HPI Negara ketertiban umum dipergunakan sebagai pembatas terhadap berlakunya hukum asing (lex causae), namun jika pemakaian hukum asing itu menyebabkan pelanggaran terhadap peraturan nasional, maka hakim dapat mengesampingkan hukum asing tersebut. Sehingga dengan jelas kedudukan pilihan hukum dalam penyelesaian sengketa asuransi pengangkutan laut ini dapat diselesaikan di Pengadilan Negeri. Prosedur dalam penyelesaian sengketa asuransi pengangkutan laut atas kewenangan mengadili pilihan hukum tidak dilihat dari kewenangan absolut semata, melainkan juga dilihat dari isi perjanjian yang dimana pilihan hukum telah disepakati secara sepihak untuk menggunakan hukum inggris, namun telah dibantah dalam banding Mahkamah Agung, sehingga dilihat dari perjanjian yang dibuat di Bali, Indonesia, dengan para pihak berbadan hukum yang berdiri atas hukum yang ada di Indonesia, barang yang dikirim dari Indonesia menuju negara Amerika, maka penyelesaian sengketa diselesaikan di Pengadilan Negeri Denpasar.

\section{Saran}

Terkait simpulan penelitian tersebut, adapun saran yang diberikan yaitudiharapkan kepada PT. Tirta Internasional Cargo dalam membuat suatu perjanjian seharusnya lebih baik dalam menyampaikan isi perjanjian dan dalam isi perjanjian harus jelas penulisan agar bisa dengan jelas dibaca oleh pihak penerima asuransi perjanjian tersebut. Lembaga peradilan dalam hal menyelesaikan sengketa asuransi pengangkutan laut yang banyak menggunakan hukum asing agar tidak tergesa-gesa mengambil keputusan dalam menyelesaikan sengketa, lembaga peradilan seharusnya lebih memahami teori-teori yang bisa digunakan lembaga peradilan agar berwenang untuk menyelesaikan sengketa asuransi pengangkutan laut.

\section{DAFTAR PUSTAKA}

Bambang, W. (2002). Penelitian Hukum dalam Praktek. Jakarta: Sinar Grafika.

EkardSoekardono. (1969). Hukum Perkapala di Indonesia. Jakarta. Dian Rakyat.

Fuady, M. (2007). Hukum Kontrak dari Sudut pandang Hukum Bisnis. Bandung. Citra Aditya Bakti.

Gautama, S. (1977). Hukum Antar Tata Hukum. Bandung. Alumni.

Gautama, S. (2007). Hukum Perdata Internasional Indonesia. Bandung. Alumni.

Marthen, N. (2015). Tinjauan Yuridis Tanggungjawab Nakhoa dalam Pengangkutan Barang di Laut. Jurnal Ilmu Hukum Legal Opinion, 3(6), 1-14.

Moertiono, R. J. (2019). Penyelesaian Sengketa Pengangkutan Laut. Jurnal Penelitian Pendidikan Sosial Humaniora, 4(1), 484-492.

Nasution, A. (1999). Pengantar Hukum Perlindungan Konsumen. Jakarta. Daya Widya.

Pakaya, U. (2017). Bahasa Hukum Dalam Putusan Perkara Pidana. Negara Hukum, 8(1), 151-175.

Siswanto, A. H., \& Sari, F. I. (2010). Tinjauan Yuridis terhadap Abandonemen ( Penyerahan Hak Milik Atas Benda Pertanggungan ) dalam Hal Penyelesaian Klaim Asuransi Rangka Kapal (Marine Hull Insurance). Lex Jurnal, 7(2), 150-161. 